\title{
Hubungan sikap peduli lingkungan dengan partisipasi dalam memelihara lingkungan pada pedagang di Pasar Kalibaru Cilincing, Jakarta Utara
}

\section{The relationship between environmental care attitudes and participation in preserving the environment for traders at Kalibaru Cilincing Market, North Jakarta}

\author{
T. P. Anggraeni ${ }^{1 *}$, M. Japar ${ }^{1}$, I. Syafrudin ${ }^{1}$ \\ 1Program Studi Pendidikan Pancasila dan Kewarganegaraan, Universitas Negeri Jakarta, Jakarta, \\ Indonesia
}

\begin{abstract}
Abstrak.
Partisipasi dalam memelihara lingkungan dapat dipengaruhi oleh sikap, karena sikap memunculkan respon untuk berbuat. Tujuan penelitian ini untuk memperoleh data empiris mengenai hubungan antara sikap peduli lingkungan dengan partisipasi memelihara lingkungan pada pedagang di Pasar Kali Baru Cilincing, Jakarta Utara. Metode yang digunakan adalah metode regresi sederhana dengan pendekatan kuantitatif. Penelitian ini dilakukan terhadap 72 pedagang. Hasil pengolahan data menunjukkan regresi linier sederhana $\hat{Y}=0,439+0,787 X$. Uji keberartian regresi diperoleh Fhitung 39,964 > Ftabel 3,98 hal ini menunjukkan model regresi signifikan. Pada uji linieritas diperoleh $\mathrm{F}_{\text {hitung }} 0,638<\mathrm{F}_{\text {tabel }}$ 1,775 dengan demikian regresi bersifat linier. Selanjutnya korelasi produk momen diperoleh $\mathrm{r}_{\text {hitung }} 0,576>\mathrm{r}_{\text {tabel }} 0,231$ artinya terdapat hubungan yang positif. Uji signifikansi hubungan diperoleh $t_{\text {hitung }} 7,201>t_{\text {tabel }} 1,994$ artinya hubungan antara variabel Sikap Peduli Lingkungan (X) dengan variabel Partisipasi Memelihara Lingkungan (Y) adalah signifikan. Koefisien korelasi sebesar $\mathrm{r}_{\mathrm{xy}}=0,576$. Koefisien determinasi sebesar $\mathrm{r}_{\mathrm{xy}}{ }^{2}=0,331$ artinya variabel $\mathrm{X}$ berkontribusi terhadap variabel Y sebesar 33,1\%. Berdasarkan penelitian ini, diketahui terdapat hubungan yang positif antara sikap peduli lingkungan dengan partisipasi dalam memelihara lingkungan.
\end{abstract}

Kata kunci: memelihara lingkungan, pasar, partisipasi, peduli lingkungan, sikap

\begin{abstract}
.
Participation in maintaining the environment can be influenced by the attitude, because it has will elicit a response to act. The purpose of this study was to obtain empirical data regarding the relationship between environmental care attitudes and participation in preserving the environment for traders at Kali Baru Cilincing Market, North Jakarta. The method used was a simple regression method with a quantitative approach. This research was conducted on 72 traders. The results show that simple linear regression $\hat{Y}=0,439+0,787 X$. Regression significance test obtained $F_{\text {count }}$ $39,964>F_{\text {table }} 3,98$, this indicates the regression model was significant. In the linearity test, $F_{\text {count }} 0,638<F_{\text {table }} 1,775$, thus the regression was linear. Furthermore, the product moment correlation test obtained $r_{\text {count }} 0,576>r_{\text {table }} 0,231$, so there was a positive relationship. The significance test of the relationship was obtained $t_{\text {count }} 7,201>t_{\text {table }} 1,994$, meaning that the relationship between Environmental Care Attitude $(X)$ and Participation in Preserving the Environment $(Y)$ was significant. The correlation coefficient of 0,576. The coefficient of determination of 0,331 means that the $X$ variable contributes to the Yvariable by $33,1 \%$. Based on this research, there was a positive relationship between environmental care attitudes and participation in preserving the environment.
\end{abstract}

Keywords: preserving the environment, market, participation, environmental care, attitude

\section{PENDAHULUAN}

Permasalahan lingkungan yang terjadi tidak menutup kemungkinan merupakan campur tangan manusia, karena kehidupan manusia selalu beriringan dengan lingkungannya. Kehidupan yang berjalan saat ini merupakan kehidupan tanpa batas dengan pertumbuhan jumlah manusia dan aktivitas yang

\footnotetext{
${ }^{*}$ Korespondensi Penulis

Email : titaniapa30@gmail.com
} 
semakin banyak adanya. Aktivitas manusia akan mengalami berbagai hambatan apabila keadaan bumi dan lingkungan tidak mampu lagi menahan aktivitas dan jumlah manusia. Lingkungan hidup sejatinya bukan hanya milik generasi saat ini, melainkan juga generasi penerus di masa mendatang. Upaya yang perlu dilakukan untuk menjaga lingkungan ialah dengan melakukan tindakan nyata penyadaran tentang pentingnya menjaga lingkungan dan melakukan berbagi tindakan langsung dalam kehidupan sehari-hari.

Menciptakan lingkungan yang bersih merupakan tanggung jawab bersama masyarakat baik di sekitar lingkungan rumah, sarana ibadah, sarana pendidikan, sarana kesehatan dan tempat umum. Pemeliharaan kebersihan yang baik di lingkungan pasar sangat diperlukan untuk menjaga kebersihan. Berdasarkan PerDa Provinsi DKI Jakarta Nomor 3 Tahun 2013, masyarakat memiliki hak dan kewajiban untuk melakukan partisipasi dalam memelihara kebersihan di lingkungannya agar terwujudnya lingkungan yang bersih. PerMenDaGri Nomor 20 Tahun 2012 Pasal 14 menyebutkan bahwa pemakai tempat usaha berkewajiban untuk menjaga kebersihan, keamanan, serta ketertiban tempat usaha (Ami Jaya 2016).

Di tengah masyarakat yang terus berkembang Pasar Kali Baru, pasar tradisional yang ada tetap bertahan keberadaannya. Pasar Kali Baru memiliki berbagai jenis pedagang yang dibagi pada beberapa blok atau los antara lain pedagang perhiasan, pedagang pakaian, pedagang makanan dan minuman, pedagang kebutuhan sehari-hari, pedagang ikan dan daging, pedagang sayur dan buah. Pasar Kali Baru masih menggunakan transaksi jual beli dengan sistem tawar menawar harga antar pedagang dan pembeli.

Pasar yang memiliki intensitas kegiatan yang tinggi, maka perlu dilakukan usaha dalam meningkatkan kesehatan lingkungan, dengan rasa kesadarannya untuk berpartisipasi terhadap kebersihan lingkungannya dalam penanganan sistem persampahan, pembuangan air, penataan kios, serta los pedagang. Hal tersebut merupakan tanggung jawab bersama pemerintah serta masyarakat atau pedagang pasar (Aperta 2016). Tindakan seseorang dalam berperilaku sehari-hari dipengaruhi oleh sikap setiap masing-masing individu. Selain sikap itu sendiri terdapat faktor lain yaitu lingkungan dan keyakinan seseorang.

Beraneka jenis produk yang dibutuhkan masyarakat dijualbelikan di Pasar Kali Baru. Produk yang dijual sudah pasti menyisakan hasil dari produk yang tidak dapat dijual lagi. Hal tersebut dapat menimbulkan sampah yang jika tidak ditangani dengan benar akan menyebabkan masalah. Untuk mengurangi dan menghindari masalah tersebut diperlukannya sikap peduli lingkungan dari seluruh warga pasar untuk berpartisipasi dalam memelihara lingkungan pasar. Berpartisipasi dalam memelihara lingkungan tidak hanya mengandalkan petugas pasar saja namun peran yang sangat penting adalah peran dari pedagang 
pasar itu sendiri. Bentuk partisipasi memelihara lingkungan pasar dapat berbentuk berupa ide/gagasan, tenaga, dan modal. Partisipasi inilah yang dapat menciptakan lingkungan pasar yang bersih. Berdasarkan permasalahan tersebut, penelitian ini mempunyai tujuan untuk menguraikan hubungan sikap peduli lingkungan dengan partisipasi dalam memelihara lingkungan para pedagang di Pasar Kalibaru Cilincing, Jakarta Utara.

Partisipasi adalah keterlibatan seseorang secara mental, perasaan serta fisik dalam suatu kegiatan yang dilaksanakan dengan menggunakan segala kemampuannya yang mendukung dalam mencapai tujuan serta bertanggung jawab atas keterlibatannya (Yusuf 2019). Menurut Soelaiman (1985) dalam Yulianti (2006), partisipasi masyarakat merupakan keterlibatan warga masyarakat secara aktif, secara perorangan, kelompok, atau kesatuan masyarakat yang dilakukan di dalam ataupun luar lingkungan atas dasar kesadaran dan tanggung jawab dalam proses pembuatan keputusan bersama, perencanaan, pelaksanaan program dan pembangunan masyarakat.

Partisipasi masyarakat merupakan sebuah pengembangan mutu bersama tolong-menolong atas dasar inisiatif, kesediaan terhadap usaha rancangan yang berisi tujuan dan strategi untuk mencapai tujuan. Partisipasi merupakan faktor utama dalam mendukung keberhasilan atau pencapaian tujuan. Keberhasilan dari tujuan dinyatakan berhasil apabila masyarakat ikut berpartisipasi aktif dalam proses tersebut dan memberikan dampak terhadap apa yang dilakukannya. Sama halnya dengan partisipasi masyarakat dalam memelihara lingkungan agar lingkungan tetap lestari diperlukannya partisipasi aktif dari masyarakat. Melestarikan lingkungan bukan hanya peran pemerintah melainkan anggota masyarakat juga harus terlibat dalam memelihara lingkungannya.

Menurut UU Nomor 32 Tahun 2009 Pasal 70 ayat, masyarakat memiliki hak dan kesempatan yang sama dan seluas-luasnya untuk berperan aktif dalam perlindungan dan pengelolaan lingkungan hidup. Lebih lanjut menurut peraturan yang sama, peran masyarakat berupa pengawasan sosial, pemberian saran, pendapat, usul, keberatan, dan/atau pengaduan, serta penyampaian informasi dan/atau laporan. Sastropoetro (1986) dalam Sulistiyorini et al. (2015) menyebutkan macam partisipasi yaitu, pemikiran, tenaga, pemikiran dan tenaga, keahlian, barang, dan uang. Partisipasi masyarakat merupakan kepedulian masyarakat terhadap kualitas lingkungannya, seperti mengikuti kegiatan sosial yang ada di lingkungannya, misal ikut serta dalam kegiatan kerja bakti, menjaga dan membersihkan saluran air. Masyarakat merupakan pelaku, subjek, sekaligus merupakan bagian dari tujuan pengelolaan lingkungan. Perkembangan manusia yang didukung oleh lingkungan yang ideal maka akan menjadi lebih baik, dan perkembangan lingkungan akan ideal ketika didukung oleh manusia yang baik. 
Sikap merupakan respon seseorang terhadap stimulus atau objek tertentu, yang dipengaruhi oleh faktor emosi dan pendapat, seperti senang atau tidak senang, baik atau buruk, setuju atau tidak setuju, dan lainnya. Sikap diistilahkan pula sebagai kecenderungan perilaku atau reaksi masyarakat yang belum menjadi suatu tindakan atau kegiatan (Rahmadani 2017). Ellis (2007) dalam Suharyat (2009) mengutarakan bahwa pengetahuan terlibat dalam menentukan sikap. Tetapi dalam sikap, perasaan atau emosi merupakan aspek esensial yang menentukan kecenderungan atas perbuatan yang berhubungan dengan pengetahuan. Sesuatu lain yang terlibat adalah situasi yang dikatakan sebagai gambaran suatu objek yang akan memengaruhi emosi atau perasaan, lalu memunculkan respon atau kecenderungan untuk berbuat. Dalam kehidupan sehari-hari, seseorang dihadapkan dengan berbagai pilihan dalam bersikap pada kondisi dan situasi tertentu, baik maupun buruk, bermanfaat maupun tidak.

Kehidupan antara manusia dan alam saling bergantung, manusia berperan sebagai subjek yang mengambil manfaat dari alam sebagai penunjang kelangsungan hidupnya. Namun dalam memanfaatkan sumber daya alam, terkadang manusia lupa diri (Narut dan Nardi 2019), sehingga diperlukan sikap peduli lingkungan guna menjaga kelestarian lingkungan. Peduli terhadap lingkungan merupakan tindakan yang bertujuan untuk mencegah kerusakan dan memperbaiki kerusakan lingkungan (Narut dan Nardi 2019). Peduli terhadap lingkungan berarti menjaga fungsi lingkungan termasuk bijaksana dalam menata, memanfaatkan, mengembangkan, memelihara, memulihkan, mengawasi serta mengendalikan lingkungan (Apriliyana 2016).

Indikator peduli lingkungan menurut KLH yaitu, perilaku hidup sehat, membuang sampah, perilaku hemat energi, memanfaatkan air dan penyumbang emisi karbon. Terdapat indikator sikap peduli lingkungan yang bertujuan untuk pengupayaan pencegahan kerusakan lingkungan, yaitu: (1) merawat lingkungan; (2) pengurangan penggunaan plastik; (3) pengelolaan sampah sesuai jenisnya, memilah sampah dan membuang berdasarkan jenis; (4) pengurangan emisi karbon; (5) penghematan energi, menjaga ketersediaan air bersih dan menggunakan listrik secara efisien (Irfianti et al. 2016). Peduli terhadap lingkungan dapat diekspresikan melalui sikap mendukung atau memihak lingkungan yang diwujudkan melalui tindakan nyata yang dapat menjaga dan meningkatkan kualitas lingkungan (Rochimah 2018).

\section{METODOLOGI}

\subsection{Lokasi kajian dan waktu penelitian}

Penelitian ini dilakukan pada bulan Februari-Juni 2021 di Pasar Kalibaru yang beralamat di Jalan Kosambi Timur 2, Kelurahan Kalibaru, Kecamatan Cilincing, Jakarta Utara. 


\subsection{Metode pengambilan sampel}

Sampel dalam penelitian ini adalah seluruh pedagang yang berjualan di dalam gedung Pasar Kalibaru. Jumlah sampel sebanyak 72 pedagang. Dalam pengambilan sampel menggunakan teknik purposive sampling. Teknik wawancara terhadap 72 pedagang dengan menggunakan kuesioner dengan menggunakan Skala Likert.

\subsection{Pengumpulan Data}

Pengumpulan data pada variabel sikap peduli lingkungan menggunakan kuesioner dengan Skala Likert yang terdiri dari lima kategori yaitu Sangat Setuju (ST), Setuju (S), Ragu-ragu (RR), Kurang Setuju (KS), dan Tidak Setuju (TS). Pernyataan positif ST bernilai 5, S bernilai 4, RR bernilai 3, KS bernilai 2, TS bernilai 1 , sedangkan untuk pernyataan negatif ST bernilai $1, S$ bernilai 2 , RR bernilai 3, KS bernilai 4, TS bernilai 5 . Indikator sikap peduli lingkungan dijelaskan pada Tabel 1.

Tabel 1. Sikap peduli lingkungan.

\begin{tabular}{lc}
\hline Indikator & Jumlah Pertanyaan \\
\hline Perawatan lingkungan & 14 \\
Pengurangan penggunaan plastik & 4 \\
Pengelolaan sampah & 7 \\
Pengurangan emisi karbon & 2 \\
Penghematan energi & 4 \\
\hline \multicolumn{1}{c}{ Total } & 31 \\
\hline
\end{tabular}

Pengumpulan data pada variabel partisipasi memelihara lingkungan menggunakan kuesioner dengan Skala Likert yang terdiri dari lima kategori yaitu Sering (SR), Selalu (SL), Kadang-Kadang (KK), Pernah (P), dan Tidak Pernah (TP). Pernyataan positif SR bernilai 5, SL bernilai 4, KK bernilai 3, P bernilai 2 , TP bernilai 1, sedangkan untuk pernyataan negatif SL bernilai 1 , SR bernilai 2 , KK bernilai $3, \mathrm{P}$ bernilai 4 , TP bernilai 5 . Indikator partisipasi memelihara lingkungan dijelaskan pada Tabel 2.

Tabel 2. Partisipasi memelihara lingkungan.

\begin{tabular}{|c|c|}
\hline Indikator & Jumlah Pertanyaan \\
\hline Pemikiran & 10 \\
\hline Tenaga & 7 \\
\hline Keahlian & 7 \\
\hline Barang & 1 \\
\hline Uang & 3 \\
\hline Total & 28 \\
\hline
\end{tabular}




\subsection{Prosedur analisis data}

Metode analisis data yang digunakan adalah metode deskriptif kuantitatif menggunakan analisis regresi sederhana dengan variabel bebas (x) adalah sikap peduli lingkungan dan variabel terikat $(\mathrm{y})$ adalah partisipasi dalam memelihara lingkungan. Penjelasan tahapan-tahapan yang dilakukan adalah sebagai berikut.

1. Uji Prasyarat

a. Uji normalitas, untuk mengetahui data terdistribusi normal atau tidak dengan menggunakan metode Liliefors pada tingkat signifikansi $\alpha=0,05$.

b. Uji persamaan regresi, menggunakan persamaan regresi linier sederhana.

2. Uji Hipotesis

a. Uji signifikansi (keberartian) regresi, yang bertujuan untuk memperkirakan kaitan yang terjadi antara variabel bebas (x) dengan variabel terikat (y).

b. Uji linieritas regresi.

c. Uji korelasi, digunakan untuk melihat sejauh mana hubungan antara variabel bebas (x) dan variabel terikat (y), menggunakan rumus Pearson Product Moment.

d. Uji $t$, digunakan untuk mengetahui keberartian hubungan atau taraf signifikansi variabel.

e. Uji koefisien determinasi, dilakukan untuk melihat seberapa besar kontribusi variabel bebas $(\mathrm{x})$ terhadap variabel terikat $(\mathrm{y})$.

\section{HASIL DAN PEMBAHASAN}

\subsection{Frekuensi nilai sikap peduli lingkungan}

Berdasarkan hasil penelitian, diperoleh data skor tertinggi 144, skor terendah 96 , skor rata-rata 123,20 , median 123,5 , modus 123 , varians 139,875 , dan standar deviasi 11,83. Frekuensi pada rentang skor 124-130 merupakan yang tertinggi dan terdapat pada kelas kelima dengan responden sebanyak 16 (22\%), sedangkan rentang skor 96-102 merupakan frekuensi terendah yang terdapat pada kelas pertama dengan 3 responden (4\%) (Gambar 1).

\subsection{Frekuensi nilai partisipasi memelihara lingkungan}

Pada variabel ini diperoleh data skor tertinggi 134, skor terendah 46, skor rata-rata 97,5, median 96, modus 100 , varians 261,29, dan standar deviasi 16,16. Frekuensi pada rentang skor 85-97 merupakan frekuensi tertinggi yang terdapat pada kelas kelima dengan 24 responden (33\%), sedangkan rentang skor 46-58 merupakan frekuensi terendah yang terdapat pada kelas pertama dengan 1 responden (1\%) (Gambar 2). 


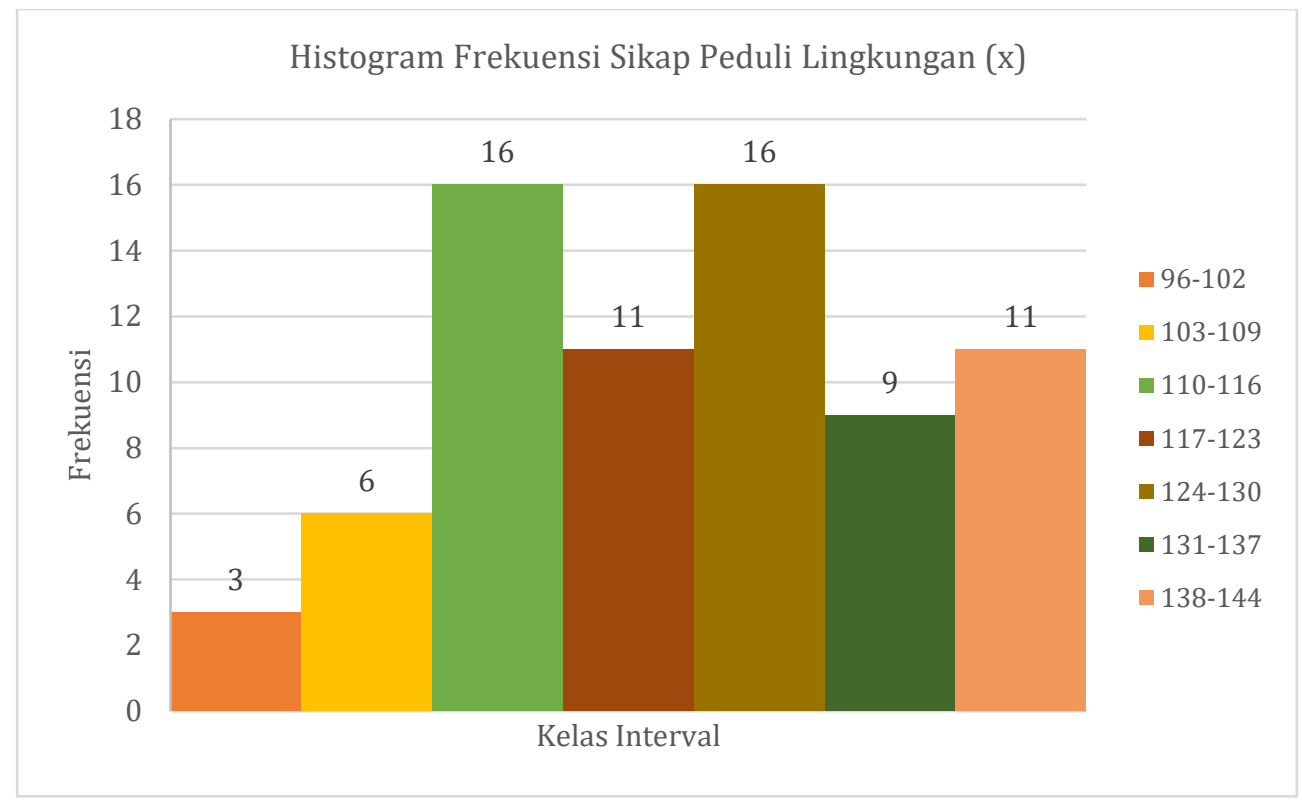

Gambar 1. Histogram distribusi frekuensi nilai sikap peduli lingkungan.

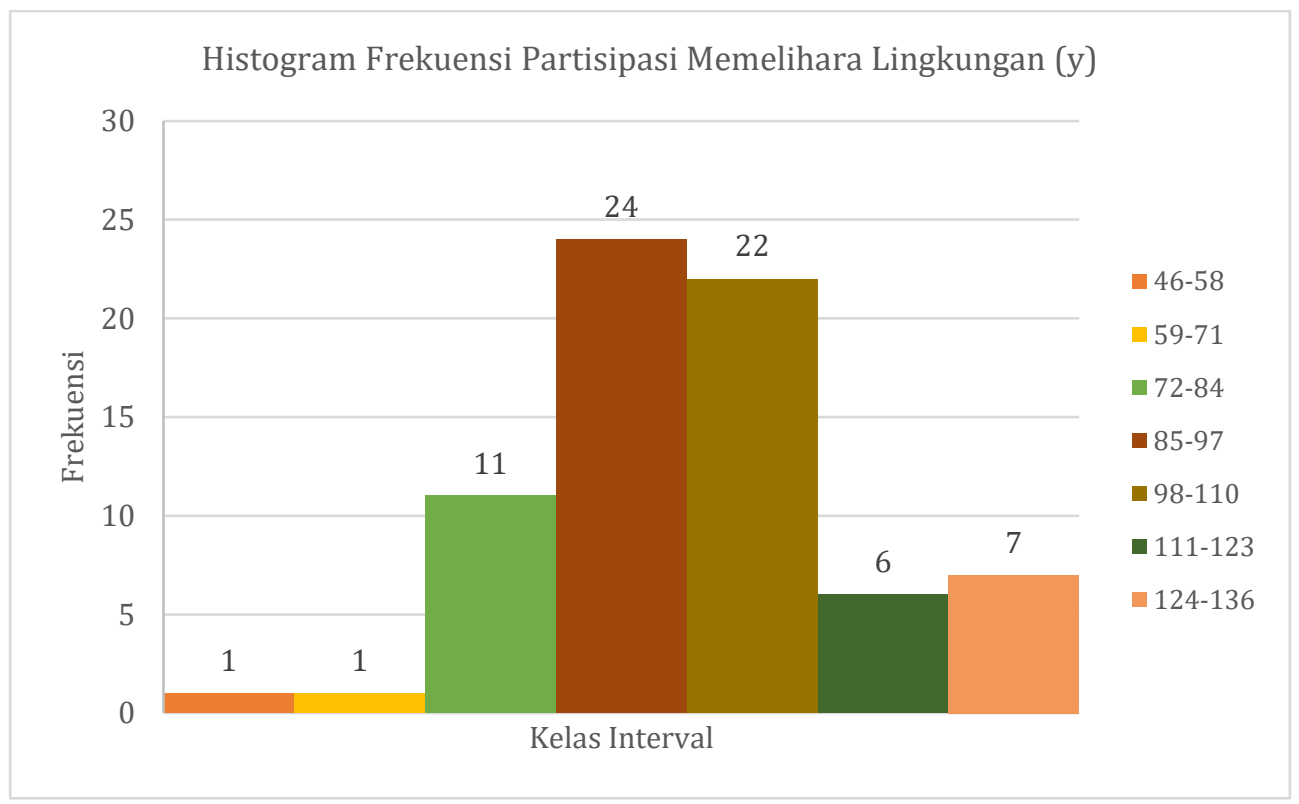

Gambar 2. Histogram distribusi frekuensi nilai partisipasi memelihara lingkungan.

Penguraian data di atas yang diperoleh dari masing-masing variabel bertujuan untuk memberikan deskripsi variabel dan menggambarkan karakter sampel. Pada sub bab selanjutnya dibahas mengenai korelasi dari masingmasing variabel penelitian. 


\subsection{Korelasi antara sikap peduli lingkungan dan partisipasi memelihara lingkungan}

Berdasarkan hasil analis data, diperoleh bahwa masing-masing variabel memiliki data yang terdistribusi normal. Dikatakan normal karena hasil perhitungan variabel sikap peduli lingkungan ( $\mathrm{x}$ ) diperoleh Lhitung $\max =0,052$ dan Ltabel $(72 ; 0,05)=0,125$. Hal tersebut menunjukkan Lhitung $<$ Ltabel, sehingga data variabel $\mathrm{x}$ dikatakan terdistribusi normal. Pada variabel partisipasi memelihara lingkungan $(\mathrm{y})$ diperoleh Lhitung $\max =0,049$ dan Ltabel $(72 ; 0,05)=$ 0,125, hal tersebut menunjukkan Lhitung < Ltabel, sehingga data variabel y juga dikatakan terdistribusi normal. Pada persamaan regresi diperoleh $\hat{Y}=0,439+0,787 X$ yang menunjukkan adanya hubungan positif antara sikap peduli lingkungan dengan partisipasi memelihara lingkungan (Gambar 3).

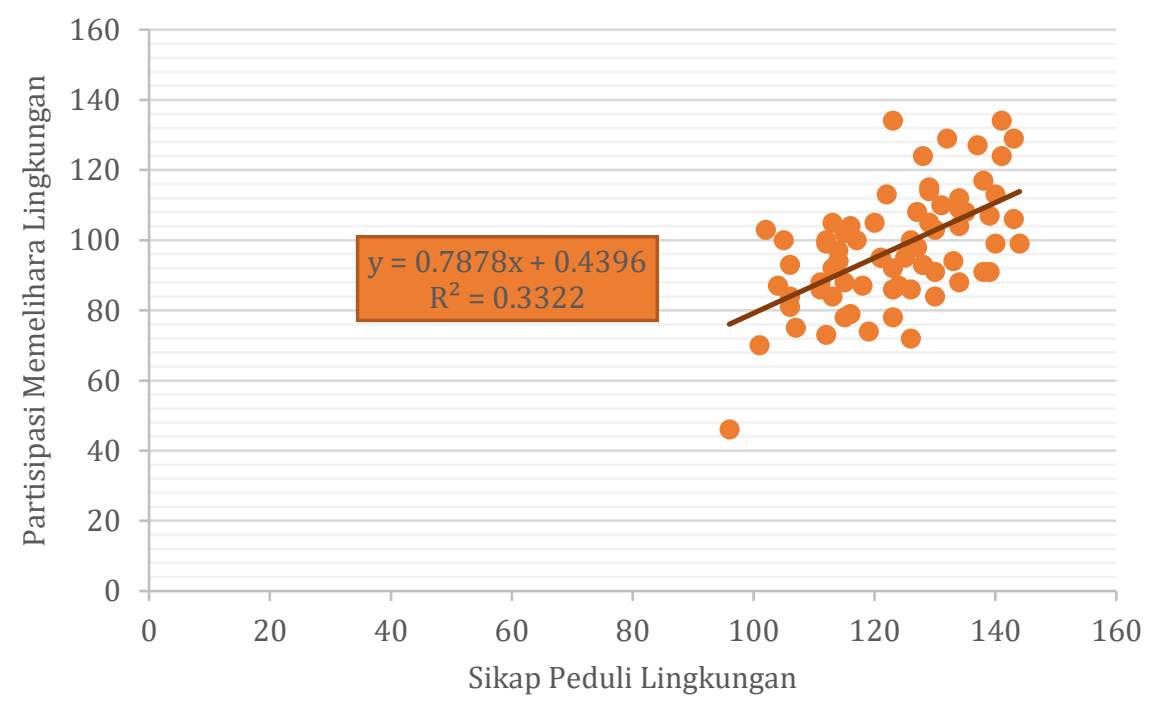

Gambar 3. Regresi sikap peduli lingkungan dengan partisipasi memelihara lingkungan.

Hasil hitung uji keberartian regresi memperoleh $F_{h i t u n g}=39,964$, sedangkan $F_{\text {tabel }}(0,05 ; 1 / 70)=3,98$ berarti $F_{\text {hitung }}>F_{\text {tabel}}$, sehingga model regresi signifikan. Hasil analisis data menggunakan korelasi product moment menunjukkan hasil $r_{\text {hitung }}=0,576$ dan $r_{\text {tabel }}=0,231$, karena $r_{\text {hitung }}>r_{\text {tabel }}$ dengan demikian sikap peduli lingkungan dengan partisipasi memelihara lingkungan memiliki hubungan positif dan berada pada interval 0,400-0,599 dengan kategori cukup kuat. Hubungan antara sikap peduli lingkungan dengan partisipasi memelihara lingkungan memiliki keberartian atau signifikan, hal tersebut berdasarkan pada hasil uji t dengan thitung $=7,201$ yang lebih besar dari tabel $=1,994$. Besarnya 
kontribusi sikap peduli lingkungan terhadap partisipasi dalam memelihara lingkungan sebesar $33,1 \%$ hasil tersebut diperoleh dari perhitungan menggunakan rumus koefisien determinasi. Hal ini menunjukkan bahwa sikap peduli lingkungan memberikan kontribusi sebesar 33,1\% terhadap partisipasi memelihara lingkungan, sedangkan sisanya dipengaruhi oleh variabel lain seperti pengetahuan, pemahaman, dan perilaku.

\section{KESIMPULAN DAN SARAN}

Berdasarkan hasil penelitian dan pengujian, diperoleh hubungan yang positif dan signifikan antara sikap peduli lingkungan dengan partisipasi memelihara lingkungan pada pedagang di Pasar Kali Baru Jakarta Utara. Penelitian ini menghasilkan informasi bahwa jika pedagang memiliki sikap peduli lingkungan maka akan mempengaruhi partisipasi pedagang dalam memelihara lingkungan. Pemeliharaan lingkungan di Pasar Kali Baru sudah cukup baik, namun alangkah lebih baiknya agar terus ditingkatkan lagi untuk tetap menjaga kondisi lingkungan yang tetap bersih dan nyaman, serta sebaiknya lebih sering melakukan tugasnya untuk tetap menjaga kondisi lingkungan pasar yang bersih dan nyaman.

\section{DAFTAR PUSTAKA}

Ami Jaya DT. 2016. Hubungan antara sikap pedagang terhadap kebersihan lingkungan dengan partisipasi menjaga kebersihan lingkungan pasar (survei pada pedagang di Pasar Bintara, Bekasi Barat) [Skripsi]. Pendidikan Ilmu Pengetahuan Sosial, Fakultas Ilmu Sosial, Universitas Negeri Jakarta. Jakarta.

Aperta R. 2016. Partisipasi pedagang dalam pelaksanaan kebersihan ketertiban dan keindahan di Pasar Pagi Arengka Pekanbaru. JOM FISIP 3(2):1-10.

Apriliyana E. 2016. Peningkatan sikap peduli lingkungan dan prestasi belajar IPS materi ekonomi pemanfaatan sumber daya alam metode field study di kelas IV SD Negeri 1 Kalitengah Purwanegara [Skripsi]. Apriliyana E. 2016. Peningkatan sikap peduli lingkungan dan prestasi belajar IPS materi ekonomi pemanfaatan sumber daya alam metode field study di kelas IV SD N 1 Kalitengan Purwanegara [Skripsi]. Program Studi Pendidikan Guru Sekolah Dasar, Fakultas Keguruan dan Ilmu Pendidikan, Universitas Muhammadiyah Purwokerto. Purwokerto.

Irfianti MD, Khanafiyah S dan Astuti B. 2016. Perkembangan karakter peduli lingkungan melalui model experiential learning. Unnes Physics Education Journal 5(3):72-79. 
Narut YF dan Nardi M. 2019. Analisis sikap peduli lingkungan pada siswa kelas VI sekolah dasar di Kota Ruteng. Scholaria: Jurnal Pendidikan dan Kebudayaan 9(3):259-266.

PerDa (Peraturan Daerah) Provinsi Daerah Khusus Ibukota Jakarta Nomor 3 Tahun 2013 tentang pengelolaan sampah.

PerMenDaGri (Peraturan Menteri Dalam Negeri) Nomor 20 Tahun 2012 tentang pengelolaan dan pemberdayaan pasar tradisional.

Rahmadani E. 2017. Hubungan pengetahuan, sikap, dan ketersediaan sarana pengelolaan sampah dengan partisipasi pedagang dalam pengelolaan sampah di Pasar Raya Solok tahun 2017 [Skripsi]. Program Studi Diploma 4 Kesehatan Lingkungan, Politeknik Kesehatan Kementerian Kesehatan Padang. Padang.

Rochimah SN. 2018. Peningkatan sikap peduli lingkungan menggunakan media pop up berbasis karakter pada siswa kelas IA SD Muhammadiyah Pepe [Skripsi]. Pendidikan Guru Sekolah Dasar, Fakultas Ilmu Pendidikan, Universitas Negeri Yogyakarta. Yogyakarta.

Suharyat Y. 2009. Hubungan antara sikap, minat, dan perilaku manusia. REGION $1(3)$.

Sulistiyorini NR, Darwis RS dan Gutama AS. 2015. Partisipasi masyarakat dalam pengelolaan sampah di lingkungan Margaluyu kelurahan Cicurug. Share Social Work Jurnal 5(1):71-80.

UU (Undang-Undang) Nomor 32 Tahun 2009 tentang perlindungan dan pengelolaan lingkungan hidup.

Yulianti. 2006. Partisipasi masyarakat dalam perbaikan dan pemeliharaan lingkungan permukiman di Kelurahan Batu Sembilan, Kecamatan Tanjungpinang Timur [Tesis]. Program Studi Magister Pembangunan Wilayah dan Kota, Program Pascasarjana, Universitas Diponegoro. Semarang.

Yusuf M. 2019. Partisipasi masyarakat dalam pembangunan di gang tanjung kelurahan sungai pinang luar kota Samarinda. eJournal Ilmu Pemerintahan 7(4):1849-1860. 